\title{
3 Trade, Tax, and Development Finance
}

\author{
Understanding China's Choice of BRI Agreements and \\ Institutions
}

Michael Sampson, Jue Wang and Irma Mosquera Valderrama

\begin{abstract}
Chapter 3 examines the decisions that inform the BRI's institution building. It explores the tension between strategic and efficiency-oriented concerns, tracing these tensions across three issue areas: tax, trade, and development finance. The chapter shows that, in dealing with challenges, the Chinese government lacks an integral governance framework that systemically coordinates all relevant institutions. Instead, it takes varied institutional approaches to overseeing BRI projects, ranging from bilateral trade agreements to multilateral financial institutions. This raises the question of what is driving China's development of agreements and institutions for the BRI. The chapter argues that China's development of BRI tax initiatives is mostly motivated by efficiency drivers, its trade agreements with key BRI partners by strategic drivers, and its efforts to establish multilateral financial institutions by both drivers.
\end{abstract}

Keywords: Belt and Road Initiative, agreements, institutions, trade, tax, development finance

\section{What Is Driving the Belt and Road Initiative?}

There has been much academic and policy debate around the factors driving the Belt and Road Initiative (BRI) in recent years: Is the BRI an attempt by China to dramatically improve its power position in Asia? Or is it simply a mechanism by which China can support its own economic growth by providing markets for exports and returns on its investments? (De Soyres et al. 2019; Rahman \& Shurong 2017; Wang 2016) This debate has tended to operate at a high level

Schneider, Florian (ed.), Global Perspectives on China's Belt and Road Initiative: Asserting Agency through Regional Connectivity. Amsterdam, Amsterdam University Press 2021 DOI: $10.5117 / 9789463727853$ CHO3 
of generality, with less attention paid to precise mechanisms of cooperation in specific issue areas. This is partly due to the amorphous nature of the BRI project itself and partly due to its relatively recent emergence, rendering it difficult to draw definitive conclusions. This chapter provides a framework for a more precise resolution of this debate. It shows that strategic factors have more relevance in particular issue areas that fall under the umbrella of BRI cooperation whilst in other areas economic factors are much more prominent.

In this chapter we provide an analysis of three specific issue areas of cooperation under the BRI: trade, taxation, and development finance. We develop a new framework to understand why China has adopted the particular institutional approaches that it has in each issue area. By doing so, we draw more precise conclusions about the future impact of the BRI more broadly. We show that Beijing's approach has often been driven by a concern to reduce transaction costs and maximize economic advantage in its economic cooperation with BRI partners. ${ }^{1}$ We refer to these factors as the efficiency drivers of China's approach to cooperation. However, broader geopolitical concerns have also played a significant role in Beijing's approach in some instances. We refer to these factors as the strategic drivers of China's behaviour. In the following analysis we show that the priority given to each of these types of factors varies across the three issue areas. In the area of trade, broader political and strategic concerns are relatively more prominent in shaping China's institutional design choices. In the area of taxation, both strategic desires and the need to reduce transaction costs are equally important considerations. In the area of development finance, we find it particularly interesting that China has recently engaged with some multilateral development finance institutions (MDFIs), despite the greater convenience of using existing domestic institutions to finance and coordinate BRI projects, suggesting a hybrid approach in this area. China's behaviour combines strategic considerations with a concern for avoiding loss and/or maximizing the return on China's investments. In the next section we introduce the theoretical framework and define both strategic and efficiency drivers of institutional design. We then turn to area-specific analyses, providing an overview of developments, along with some of the challenges presented by cooperation in each area. In every section we draw conclusions about the most important factors driving China's behaviour. We then conclude by drawing inferences about the future impact of the BRI across these issue areas and more broadly.

1 We use 'Beijing' throughout this chapter as shorthand to refer to the central government of the PRC. 


\section{Efficiency and Strategic Concerns}

In any cooperative endeavour, state behaviour is driven by a mix of strategic and efficiency concerns, which can be thought of as concerns for gains that are either relative (how one's position can be improved vis-à-vis others) or absolute (how one's present position can be improved vis-à-vis one's own past position) (Powell 1991). But whilst recognizing this complex reality, we can be more precise about when and where each consideration wins out over the other. In the following section we operationalize efficiency (absolute gains) concerns as a desire to reduce transaction costs resulting from economic exchange. Transaction costs can be thought of as the costs incurred in the process of economic transaction between two or more parties or the 'economic equivalent of friction in physical systems' (Williamson 1985: 19). These costs can be reduced by concluding an agreement, providing certainty about the future and removing the need for repeated bargaining. In general, the more comprehensive the initial institution or contract between the parties, the greater the certainty about the future relationship. This in turn tends to mean that the costs incurred from each iterated transaction are minimized.

Where efficiency (i.e. the reduction of transaction costs) is not the driving concern, the creation and design of cooperative institutions or contracts may instead be driven by broader political or strategic considerations. Therefore, where an agreement is inefficient and limited (compared to the available and feasible alternatives) we conclude that political or strategic drivers are the primary driving force. In practice this means that agreements that result in residual uncertainty about future behaviour are more likely to be driven by strategic concerns. We define these strategic concerns as the desire to maximize the relative power position of China vis-à-vis its BRI partners.

In terms of analysing China as an actor, we find that the most fruitful approach also differs across issue areas. In international trade China can often be treated 'as if' it is a unitary actor without loss of specificity or insight, given that policy is largely influenced by two central government departments; the Ministry of Commerce (MOFCOM) and the Ministry of Foreign Affairs (MOFA). ${ }^{2}$ In finance, because this is an area in which there are a much broader variety of actors and more arm's-length institutions

2 In this sense we adopt a unitary actor assumption for China in trade, an assumption which whilst not a precise description of reality, does allow the development of useful insights. On the relationship between assumptions and description, see Friedman 1953: 8. On the unitary actor assumption in international relations, see Wendt 2004. 
operating on behalf of the government, a reduction in theoretical parsimony is warranted in order to capture the relevant factors shaping China's behaviour in this area. In tax meanwhile China's international tax policy is centralized with the main actor being the State Administration of Taxation (SAT). SAT has participated actively in OECD-, G20-, and UN-level discussion of multilateral tax initiatives to deal with base erosion and profit shifting by multinationals. SAT is also responsible for introducing regulations to deal with transfer pricing and related tax disputes. China has also created its own Belt and Road Initiative Tax Administration Cooperation Mechanism (BRITACOM) with BRI countries. The council of the BRITACOM, which is the decision-making body, is chaired by the Commissioner of the SAT.

\section{Cooperation in Trade}

From the inception of the BRI, it was envisioned as a mechanism to stimulate cooperation in infrastructure, development, finance, social and cultural exchanges, and investment and trade (Johnston 2019: 42). Given the centrality of trade to the BRI, how should we understand the cooperation occurring in this area since the launch of the initiative in 2013 ? Has China's institutional approach been driven primarily by strategic or efficiency concerns?

It is important to note that even prior to the launch of the BRI, China was party to eleven trade agreements, including a major agreement with the Association of Southeast Asian Nations (ASEAN). It was also already in the process of negotiating a broader regional pact with fifteen states in the Asian Pacific, in the form of the Regional Comprehensive Partnership (RCEP). Participant countries in these negotiations were Australia, Brunei, Cambodia, China, India, Indonesia, Japan, Laos, Malaysia, Myanmar, New Zealand, the Philippines, Singapore, South Korea, Thailand, and Vietnam (Baltensperger and Dadush 2019:2). These agreements are the result of the great deal of energy that Beijing has devoted to concluding trade deals since China's entry into the World Trade Organization (WTO) in 2001, particularly with regional partners. Though it remains difficult to precisely delineate which states actively participate in the BRI at any particular time, one study suggests that of the 44 countries that either have, or are planning, trade agreements with China, 29 also participate in BRI. Of these, sixteen are party to completed trade deals or began negotiations before the BRI was launched in 2013 (Baltensperger and Dadush 2019: 4-5). In addition to the major trade agreement with ASEAN (encompassing ten countries), China is party to bilateral trade agreements with the BRI countries Georgia, 
Pakistan, and Singapore and has concluded agreements with the territories of Hong Kong and Macao.

Interestingly, unlike other major trading powers, such as the EU, the US, or Japan, which tend to conclude broad and deep trade agreements, China has engaged in an ongoing negotiating process to expand and deepen existing agreements. This is an approach that decreases the relative efficiency of the negotiating process by increasing the number of negotiations and therefore the negotiation costs incurred. This approach also increases uncertainty by leaving many details of the initial agreements to subsequent negotiations. Therefore, compared to agreements that are comprehensive from the start, it is unclear what the implications of the final versions of China's trade agreements will be for the economic sectors involved. Such an approach also maximizes the opportunity costs of concluding comprehensive agreements from the start whilst increasing China's bargaining leverage over time. ${ }^{3}$

Alongside the reductions in tariff and non-tariff barriers that result from these formal trade agreements, improving trade facilitation is also an important part of the BRI for China (Wei et al. 2018: 1233). Trade facilitation can be broadly defined as an effort to simplify and harmonize international trade procedures to increase the efficiency of cross-border trade. Trade facilitation was formalized as part of the WTO Trade Facilitation Agreement (TFA), which was negotiated in 2013 and entered into force in 2017. Prior to this, a 2015 BRI document titled 'Vision and Actions on Jointly Building Silk Road Economic Belt and 21st-Century Maritime Silk Road' stated:

Countries along the Belt and Road should enhance customs cooperation such as information exchange, mutual recognition of regulations, and mutual assistance in law enforcement; improve bilateral and multilateral cooperation in the fields of inspection and quarantine, certification and accreditation, standard measurement, and statistical information; and work to ensure that the WTO Trade Facilitation Agreement takes effect and is implemented. (NDRC 2015; Johns et al. 2018: 12)

However, not all BRI participant states are party to the TFA because some are not WTO members; of 71 BRI countries, 58 are WTO members. Of

3 As an illustration of this point: China's trade agreements often initially only entail liberalization of trade in goods, with subsequent services agreements concluded some years later. As such the benefits of trade cooperation in services during that intervening period are lost - this is the opportunity cost. This approach also has the effect of increasing China's bargaining power, given its comparatively higher levels of economic growth and growing dependence of its trade partners. See Sampson 2019 . 
these members, as of 2018 , four have not ratified the TFA. As such, there remains scope for improvement for BRI participants on this front (Johns et al. 2018: 22-24). Trade facilitation initiatives from BRI countries are meanwhile also taking place outside of formal trade agreements. Efforts to improve transport facilitation have taken place under the auspices of the Shanghai Cooperation Organisation (SCO) and as part of the Central Asia Regional Economic Cooperation (CAREC) initiative led by the Asian Development Bank, China, Pakistan, Georgia, Azerbaijan, and seven other Central Asian countries. A treaty on facilitation of cross-border paperless trade in Asia and the Pacific was also concluded in 2016 (Ramasamy et al. 2017:14-15).

In addition to multilateral cooperation in trade, there are six main economic corridors that constitute the broader BRI: the New Eurasian Land Bridge Corridor, the China-Central Asia-West Asia (CAWA) Corridor, the China-Pakistan Corridor, the China-Russia-Mongolia Corridor, the Bangladesh-China-Myanmar Corridor, and the China-Indochina-Peninsula Corridor (Brookings 2019). It would be incorrect to assume that the level of trade cooperation and integration in each of these corridors is uniform, and in fact there is wide variation. In particular, the China-Pakistan Corridor (the only bilateral corridor) and the China-Indochina Corridor are supported by pre-existing trade agreements with Pakistan and ASEAN, respectively. In the remaining corridors no formal trade agreements exist, and the CAWA Corridor is perhaps the least well integrated as a group of countries in terms of formal trade institutions (Ramasamy et al. 2017: 18).

With respect to Pakistan, there has been cooperation in trade in which China is a crucial export destination and import source for Pakistan. In addition to this, China has also made a large number of investments in crucial infrastructure projects in Pakistan in recent years. Pakistan's level of dependence is therefore high and continues to grow (Ramasamy et al. 2017: 30). This asymmetrical relationship is exacerbated by the sequential negotiation of elements of the trade agreement. The agreements on goods and services were negotiated separately and eight rounds of trade negotiations have occurred under Phase II of the initial agreement. These culminated in negotiations to upgrade the deal in late 2016, despite Pakistan's hesitancy regarding deepening the trade relationship further (Haider 2015). Under Phase I of the agreement, Pakistan introduced zero tariffs on $35 \%$ of China's products, while China has reduced duties to $0 \%$ on $40 \%$ of Pakistan's products. Pakistan has requested revision of existing elements of the treaty because it argues that the agreement brings few economic advantages (Sampson 2019). However, given the deepening strategic relationship between 
the two states and the importance of China's investments, it is difficult to see Pakistan genuinely resisting a deepening of trade integration with China or resisting the BRI more generally. Indeed, in 2018 Pakistan had an annual trade deficit with China of over US $\$ 12$ billion. This was before the second phase of the trade agreement came into effect at the end of 2019 (Sampson 2020).

\section{Challenges in Trade}

One of the driving forces of the BRI was arguably the strategic challenge presented by the American-led Trans-Pacific Partnership (TPP) (Vines 2018: 343; Wang 2016). Though this threat to Chinese influence appears to have receded, there remain other challenges to the success of the BRI as an initiative that serves to expand China's political influence alongside its exports and investments. These challenges can be placed into two categories: technical and political.

First, there are a number of technical challenges to the success of the BRI. BRI states are becoming increasingly important players in world trade. In 2015 , they accounted for around $37 \%$ of world exports, up from $21 \%$ in 1995. With respect to the global value chain, BRI states tend to be focused on exporting mainly intermediate, rather than finished, goods and they account for a $42 \%$ share of world intermediate exports (Boffa 2018: 5) Yet despite the growing importance and interconnectedness of the BRI economies, the majority remain developing countries and as such there are still numerous technical inefficiencies that need to be resolved if the BRI is to succeed. The customs procedures in many participant countries, for example, are still outdated. This is true in all six economic corridors to varying extents. In many cases extensive customs documentation is still required for crossborder trade. This documentation process is also not supported by modern ICT infrastructure in a number of locations. In addition, there is a continued lack of harmonization of standards both within, as well as between, BRI countries (Ramasamy et al. 2017: 42)

Alongside these non-tariff issues, trade barriers between China and many BRI participants remain significant, particularly in sensitive areas such as textiles and agriculture (Cui \& Song 2019: 41). The conclusion of further trade agreements and increased coordination on trade facilitation will help to ameliorate these problems. However, there is still a long way to go in this regard. These processes will take time and progress will likely remain inconsistent. As an illustration of this, whilst there is evidence that customs and border agencies within many BRI countries are improving in terms of 
efficiency, performance in some areas has actually declined, specifically on the China-Pakistan and Bangladesh-China-India-Myanmar Corridors (Johns et al. 2018: 31). In all of the main BRI corridors, apart from the New Eurasian Land Bridge Corridor, the time that it takes to export and import goods is still above the global average. In some corridors, the time taken is well above this average (Johns et al. 2018: 29). In terms of efficiency, trade cooperation between BRI countries looks set to lag far behind cooperation in North America and Europe for quite some time.

In addition to these tricky and ongoing technical challenges, there are also the perhaps more difficult political and strategic challenges of sustaining and deepening trade cooperation between countries with vastly different economies, cultures, political systems, and geopolitical interests. There is already evidence of pushback in key partner countries such as Pakistan. In 2018, for example, Pakistan's newly elected Prime Minister Imran Kahn pledged to renegotiate agreements reached as part of the China-Pakistan Economic Corridor (CPEC) because these 'unfairly benefit Chinese companies' (Economic Times 2018).

\section{Driving Factors in Trade}

In evaluating the forces driving Beijing's approach to trade, a distinction should be drawn between multilateral cooperation around trade facilitation, which seems to be driven primarily by concerns to minimize the transaction costs involved with cross-border trade with BRI partners, and China's bilateral trade cooperation. Particularly in terms of China's bilateral trade agreements, strategic concerns seem to be significant, given the way in which China's sequential and drawn out negotiating approach increases uncertainty and negotiating costs. China's agreements often do not cover 'substantially all trade' with partner countries, and they incorporate large lists of exemptions and relatively shallow liberalization (Sampson 2019). ${ }^{4}$ At the same time the negotiations are structured in a way that maximizes China's leverage over time and are often linked to security cooperation (the case of Pakistan is a particularly prominent illustration of this). If anything, then, China's trade agreements with BRI partners do not substantially reduce uncertainty and often leave much to future negotiations.

4 GATT Article XXIV requires that free trade agreements entail 'duties and other restrictive regulations of commerce [...] are eliminated on substantially all the trade between the constituent territories in products originating in such territories'. 


\section{Cooperation in Tax}

With the BRI, China is strengthening its position as a capital export country by facilitating Chinese investment in the countries along the BRI (Europe and outside Europe). In order to strengthen this position, China is participating in already existing bilateral and multilateral tax initiatives and creating new institutional frameworks for BRI countries.

In the past, China focused on attracting investment by multinational companies into China, acting as a capital import country. However, the benefits of these activities for China's tax revenue were limited. This was due to the excessive number of tax/investment incentives in China and also due to 'base erosion profit shifting' (BEPS), a term that describes a practice where multinationals move their profits to locations with low taxes through aggressive tax planning and transfer pricing.

The BRI provides investment opportunities for Chinese companies and foreign companies in capital export countries along the BRI. These opportunities are in different sectors such as infrastructure, energy and resources, industrial development, and the financial sector. These activities will be subject to taxation in China and abroad. This means, therefore, that China's network of tax treaties will become relevant to prevent double taxation.

China has concluded more than a hundred bilateral tax treaties to prevent double taxation and tax avoidance. Approximately 50 of these tax treaties are with BRI countries (Meyer-Nandi et al. 2018). Furthermore, to tackle the base erosion profit shifting (BEPS) practices discussed above, China has participated as a member of the G2o in the OECD-G2o BEPS Project. ${ }^{5}$ In 2015, the BEPS Project introduced fifteen Actions to tackle aggressive tax planning. These included a 'Multilateral Convention to Implement Tax Treaty Related Measures to Prevent Base Erosion and Profit Shifting' ('Multilateral Instrument'), which has been in force since July 2018. China has signed this Multilateral Instrument and has expressed its intention to make this instrument applicable to almost all of the bilateral tax treaties that it has concluded (102 of 106 of its tax treaties) (OECD 2018a). This Multilateral Instrument is still pending ratification by China and therefore it has not yet entered into force there. ${ }^{6}$

5 The G2o is a political forum of governments with countries from Asia, North America, the Middle East and Europe. Following the 2008 economic crisis, the G2o has set an agenda for a higher level of international tax cooperation, e.g. G2o Summits in Los Cabos (Mexico), Washington (the United States), London (the United Kingdom) and Pittsburgh (the United States).

6 Status signatories and parties to the BEPS MLI as of 22 July 2020 retrieved 3 August 2020 from http://www.oecd.org/tax/treaties/beps-mli-signatories-and-parties.pdf. 
China is also actively taking part in the UN Committee of Experts on International Cooperation in Tax Matters. This committee aims to provide solutions to the problems faced by developing countries, including the practices of base erosion profit shifting. In some of the meetings of the UN Committee of Experts on International Cooperation in Tax Matters, for example, China has indicated that currently it does not have a system which quantitatively analyses its base erosion. However, it has also stated that: 'We do find, and it is obvious, that the major threat China faces is that many [multinational enterprises] have shifted their profits by means of tax planning and transfer pricing' (United Nations 2014: 1).

To address these initiatives in a coordinated way, in 2017 China signed a Memorandum of Cooperation (2017) alongside the other member countries of the BRICS groups of nations. ${ }^{7}$ The aim of this memorandum is to coordinate these nations' responses in international forums (such as the OECD, the United Nations) and to enhance knowledge sharing regarding BEPS implementation through the exchange of experiences on best practices.

\section{Challenges in Taxation}

The following paragraphs will address the challenges faced by China, BRI countries, and supranational organizations (such as the EU) in the implementation of international tax initiatives and BRI. These challenges are 1) increasing capacity building of tax administrations to deal with transfer pricing and related tax disputes and 2) enhancing transparency and a level playing field between China and BRI countries.

Despite China's participation in bilateral and multilateral initiatives, China's tax administration faces challenges implementing measures to deal with base erosion profit shifting because of its lack of administrative capacities. One challenge is the lack of comparable companies (i.e. a company carrying out similar economic/business activities) to make transfer pricing analysis (Avi Yonah \& Xu 2017). ${ }^{8}$ Another challenge is the number of tax/investment disputes, leading to uncertainty and unpredictability for

7 BRICS is an acronym for a group of five countries: Brazil, Russia, India, China and South Africa. The main objective is to cooperate to address common problems. Retrieved 3 August 2020 from https://infobrics.org/.

8 Avi-Yonah and $\mathrm{Xu}(2017)$ have stated that 'Chinese tax authorities makes their judgment by auditing MNE groups' annual filing and reviewing their contemporaneous documentation, considering the profit levels of the industry and comparable companies, and performing functional analysis. They then make adjustments as necessary when their judgment is made.' 
investment in China (Xu 2018a). In order to address these challenges, the State Administration of Taxation (SAT) has introduced new transfer pricing regulations and it has created additional resources for dispute settlement disputes (MAP and APAs ${ }^{9}$ ).

The SAT has introduced a transfer pricing regime that 'is now a more rigorous and comprehensive framework for regulating transfer pricing arrangements of multinational enterprises (MNEs) in China, both for inbound and outbound activity' (Cheng et al. 2019; Beng Teoh \& Wang 2019). In addition to this, a third division has been created within the SAT to assist in the handling of transfer pricing disputes. ${ }^{10}$ In this regard, Cheng et al. (2019) stated that:

$[\mathrm{P}]$ reviously, SAT resources for these matters were stretched, due to the commitment of relevant personnel to BEPS meetings from 2013 to 2015. With the new organizational structure and resources, the SAT has begun to deal with a large number of MAP cases as a matter of priority. Market intelligence indicates that a number of pending MAP cases have been reactivated with the aim of reaching an expedited solution. On the APA front, it is expected that the enhanced process introduced by the 2016 legislation (i.e. Announcement 64) will contribute to more rapid programme outcomes; this is important as the number of applications continues to increase.

Alongside these changes made by the SAT, to deal with these challenges and address the implementation of the BRI, China has launched the Belt and Road Initiative Tax Administration Cooperation Mechanism (BRITACOM). BRITACOM consists of 34 member countries, eleven countries that are observers from different regions (e.g. Asia, Africa, Europe), and one non-profit (academic) organization.

However, companies do not disclose the information, and therefore, according to these authors, 'it is unrealistic to find comparables from the over 2000 listed companies in China'.

9 A mutual agreement procedure (MAP) is a 'means through which tax administrations consult to resolve disputes regarding the application of double tax conventions'. An Advance Pricing Agreement (APA) is an 'arrangement that determines, in advance of controlled transactions, an appropriate set of criteria (e.g. method, comparables and appropriate adjustments thereto, critical assumptions as to future events) for the determination of the transfer pricing for those transactions over a fixed period of time'. Glossary (OECD 2017: 23, 28).

10 According to Cheng et al. (2019): 'There had previously been much concern that the backlog of MAP cases was affecting the processing of APA applications (MAPs and APAs are dealt with by a common team at the SAT level).' 
One of the aims of BRITACOM is to build capacity and to facilitate cooperation between the participating countries' tax administrations. In addition, BRITACOM aims to facilitate trade and investment, foster the economic growth of the BRI jurisdictions, and contribute to the fulfilment of inclusive and sustainable development as set out in the United Nations' 2030 Agenda for Sustainable Development.

In April 2019, BRITACOM countries agreed on an Action Plan for 2019-2021. According to this Plan, BRITACOM will commit 1) to the dissemination of good practices, 2) to identifying emerging issues that require joint actions, and 3 ) to seeking innovative solutions through tax administration cooperation. Furthermore, BRITACOM will contribute 4) to establishing a dialogue with business and 5) to providing more certainty by building a knowledge-sharing platform that informs investors of the interpretation and application of tax laws. BRITACOM will also 6) conduct research 'on tax certainty to identify problems, seek for solutions, increase predictability and consistency in the application of tax laws and tax treaties, as well as in tax administration practices.' ${ }^{11}$

Under the framework of BRITACOM, two new networks have been created. The first of these is the BRITACOF, which is

a non-profit official event, [which] aims to provide a platform for facilitating dialogue, strengthening cooperation in tax administration, and improving capacity building for jurisdictions, international organizations, academic institutions, businesses and other stakeholders who are willing to be involved in tax administration cooperation along the Belt and Road. ${ }^{12}$

The first BRITACOF conference took place in April 2019 and the second will take place in May 2021. ${ }^{13}$

The second network is BRITACEG, which consists of 'willing Member [tax administrations] TAs and Observers of the Council which, making full use of their existing training institutions or expertise, are dedicated to conducting tax-related training, research and technical assistance programs.' ${ }^{14}$ Through

11 Retrieved 3 August 2020 from http://www.chinatax.gov.cn/eng/n426o859/c5112272/5112272/ files/coae127d146f47aab6199320e37aee1d.pdf.

12 Retrieved 3 August 2020 from http://www.chinatax.gov.cn/eng/n4154446/common_article. html.

13 Postponed due to COVID-19. Retrieved 3 August 2020 from http://www.chinatax.gov.cn/ eng/n426o854/c5149476/content.html.

14 Retrieved 3 August 2020 from http://www.chinatax.gov.cn/eng/n4154453/common_article. html. 
this network, training courses, technical assistance, and academic research and exchange will be carried out to facilitate tax administration cooperation amongst the BRI jurisdictions.

This cooperation established in the Action Plan agreed upon by BRITACOM member countries only started recently (in 2019). It is therefore too early to evaluate this framework of cooperation. However, important elements addressed in the Action Plan, such as providing certainty for investors and facilitating cooperation between tax administrations, also need to be reinforced with initiatives to enhance transparency in the BRI process for investors outside of China. It is important to consider the concerns that have been expressed by the business sector regarding bilateral approaches to BRI that can undermine the EU as a business partner.

The EU sees the BRI as an opportunity for business in Europe. However, there are important changes that need to be made to the BRI in order to level the playing field between EU and Chinese companies. In an EU-China strategic outlook, the EU labelled China

as a cooperation partner with whom the EU has closely aligned objectives, a negotiating partner with whom the EU needs to find a balance of interests, an economic competitor in the pursuit of technological leadership, and a systemic rival promoting alternative models of governance. (EU Commission 2019:1)

One of the concerns of the EU is with the way in which some EU countries have endorsed the BRI. Some EU countries have endorsed the BRI, for instance, under the $17+1$ cooperation format signed by twelve EU member states and five western Balkan states. Others, such as Italy, Poland, and Hungary, have endorsed it through the use of a MoU with China. ${ }^{15}$ The Memorandum of Understanding $(\mathrm{MoU})$ signed between Italy and China, for example, aims to advance cooperation in transport, logistic, and infrastructure projects in the BRI, to expand trade and investment, and to strengthen bilateral communication and coordination on fiscal, financial, and structural reform policies in order to create a favourable environment for economic and financial cooperation (Memorandum of Understanding 2019b). However, adopting a bilateral position in this way reduces the role that the EU can play as a partner when dealing with China in the framework of the BRI (Van der Eijk \& Pandita Gunavardana 2019). 
Furthermore, for the EU and business associations there is a general lack of transparency in BRI investments that also affects taxation. This was highlighted in a recent BusinessEurope report (BusinessEurope 2020). The report refers to a 2018 study (Hanemann et al. 2019) that shows how, despite the $17+1$ cooperation format, 'Chinese investments in Central and Eastern EU Member States have remained low. In 2018, only $2 \%$ of all Chinese FDI into the EU was invested in Eastern European Member States' (BusinessEurope 2020: 151). This report also states that:

A 2018 survey amongst European businesses active in China demonstrated that $45 \%$ of the businesses do not see any opportunities in participating in the BRI. The survey furthermore demonstrated that many European companies are excluded from participating in the BRI because of preferential treatment of Chinese contractors, insufficient information available regarding potential projects and a lack of transparency in public procurement and tendering. (BusinessEurope 2020: 150)

Following this report, European Commissioner for Trade Phil Hogan emphasized the need to reinforce EU competitiveness and to ensure that competition is also fair in China and abroad (Hogan 2020). Thus, the benefits of the BRI for European business remain to be seen. Therefore, the actual commitment to the BRI of those countries that have either signed a MoU or endorsed it under a framework of cooperation $(17+1)$ should be closely examined.

Chinese companies carrying out BRI activities in the EU can also be susceptible to the state aid and (fair competition) tax procedures in the EU. ${ }^{16}$ According to the EU Commission, 'State aid is defined as an advantage in any form whatsoever conferred on a selective basis to undertakings by national public authorities. ${ }^{17}$ This advantage may distort fair competition and affect trade between EU countries. In 2017, China therefore concluded a MoU with the EU concerning dialogue about the state aid control regime and the Fair Competition Review System (Memorandum of Understanding 2019a).

In case that an EU country has provided an advantage to a selective group of (Chinese) companies, this advantage will be assessed in light of the EU state aid rules. This was the case in 2018, when the EU Commission

16 For the implications of EU tax rules in China, see Masseglia Miszczyszyn et al. 2020.

17 Retrieved 3 August 2020 from https:/ec.europa.eu/competition/state_aid/overview/ index_en.html. 
launched a state aid investigation into the Hungarian government's $€_{45}$ million investment aid given to the chemical company BorsodChem Zrt (a subsidiary of the Wanhua Industrial Group). In this case, the Commission assessed this investment aid based on the Guidelines on Regional State Aid for 2014-2020. These guidelines 'enable member states to support economic development and employment in EU's less developed regions and to foster regional cohesion in the Single Market' (EU Commission 2018). The Commission found that:

Without the public funding, the project would not have been carried out in Hungary or any another EU Member State, as it would have been cheaper for the beneficiary to continue importing aniline from the group's existing production plants in China. The Commission also found that the aid is limited to the minimum necessary to make the project sufficiently profitable for the company to decide to make the investment. (EU Commission 2018)

Blockmans and Hu suggested that with the approval of this investment 'the legal obstacles that the Belt and Road Initiative (BRI) had encountered in the single market of the EU were removed to serve the "community interest"' (Blockmans \& Hu 2019). They go on to state that:

While the Commission concluded that the investment in BorsodChem was not economically sound, it found that the aid would not unduly distort competition in the single market but rather help job creation, regional development and the attainment of environmental objectives. (Blockmans \& Hu 2019: 3)

\section{Driving Factors in Tax}

China has engaged actively with the OECD and the UN in implementing bilateral and multilateral tax initiatives to address international tax cooperation. This engagement has included exchanging information, preventing double taxation, and tackling aggressive tax planning. These initiatives are also of importance in the BRI since investors in the BRI will also have to deal with international taxation. Furthermore, in the framework of the BRI, China has set up an institutional framework for cooperation between BRI tax administrations, namely the BRITACOM and the two additional networks BRITACOF and BRITACEG. By contributing to these international initiatives and setting up its own institutional cooperation 
framework, China aims to foster economic growth, facilitate international tax cooperation, and assist BRI partners as they build capacities in their tax administrations.

Following these developments, it may be argued that China has engaged in these multilateral tax initiatives because of efficiency concerns - to reduce transactions costs by increasing cooperation between tax administrations participating in BRITACOM, and to increase the administrative capacity of the Chinese State Administration of Taxation (SAT) in dealing with transfer pricing disputes.

For some researchers and government officials (Blockmans \& Hu 2019), the BRI also appears to be a grand geopolitical strategy from China. This view holds that China seeks to achieve strategic aims by introducing its own mechanisms of cooperation with some EU countries. A number of problematic elements of the BRI are highlighted by countries and businesses. One is that it is neither clear nor transparent what benefits the BRI provides for participating countries. For instance, one concern from the EU regards China's use of MoUs, as well as certain other mechanisms of cooperation (such as the 17+1) with some EU countries. This diminishes the role of the EU as a partner in the BRI and increases the perception that EU businesses participating in the BRI lack an equal playing field when it comes to its benefits. Therefore, the challenge for China is to demonstrate that the BRI does not just bring economic benefits and increased investment for Chinese companies but also for foreign companies based in participating countries.

\section{Cooperation in Development Finance}

A wide range of development finance institutions are involved in BRI projects. They perform two main functions: financing and project management. These two functions are not exclusive from each other, because good project management ensures financial returns, and the two together form a sustainable mechanism of development finance. Several domestic Chinese institutions play a key role in financing and managing BRI projects. These institutions include policy banks and state-owned commercial banks, sovereign wealth funds and state-owned investment companies, as well as state-owned enterprises (SOEs). They are aligned with China's state strategy for the medium- and long-term development and they function as the state's financial tools for overseas development projects. Apart from the Silk Road Fund, most of these institutions were already active in overseas investment before the BRI was announced. 
Meanwhile, China has engaged in new MDFIs in order to strengthen BRI cooperation. In 2016, China led the establishment of the Asian Infrastructure Investment Bank (AIIB), which focuses on long-term infrastructure development in Asia. AIIB projects often share common geographical locations and development objectives with BRI projects. In addition, the Chinese Ministry of Finance is in the process of establishing the Multilateral Cooperation Center for Development Finance (MCDF). This is an institution that supports and coordinates BRI cooperation and in which the members (other than the ministry itself) are all MDFIs. This raises two questions: First, why does China engage with multilateral institutions despite the greater convenience of using domestic agencies for achieving BRI objectives through bilateral investment? Second, has China's multilateral institutional approach been driven primarily by strategic or efficiency concerns?

The Chinese policy banks and state-owned commercial banks are the most important financiers of the BRI. They provide finance for Chinese SOEs and foreign governments and corporations that are involved in BRI projects. The China Development Bank (CDB) is the world's largest development bank by total assets, and it is also one of the most active financial creditors of energy and infrastructure projects under the BRI (Carrai 2018; Sanderson \& Forsythe 2013). By March 2019, the CDB had directly provided financing of over US $\$ 190$ billion for more than 600 BRI projects (Reuters 2019). Meanwhile, the loans provided by the Export-Import Bank of China (Eximbank) for the BRI amounted to a combined value of US\$149 billion by April 2019 (Xinhua 2019a). Unlike the CDB, Eximbank also provides concessional loans and export buyer's credit for the countries that are involved in the BRI (Zhang 2018).

China's state-owned commercial banks, led by the 'Big Four' - the Industrial and Commercial Bank of China, the China Construction Bank, the Agricultural Bank of China, and the Bank of China - are also active financiers of BRI projects. This is especially the case for the Industrial and Commercial Bank of China and the Bank of China, which by April 2019 had respectively provided more than US $\$ 130$ billion and US $\$ 100$ billion for BRI projects (Xinhua 2019b). The Big Four have also initiated varied programmes in BRI countries based on their expertise. For example, the Bank of China has issued the largest amount of BRI-themed bonds to raise low-cost funding for medium- and long-term projects (Zhang 2019; Jiang 2019). The Agricultural Bank of China has particularly supported Chinese agricultural corporations to 'go out' and pursue overseas mergers and acquisitions as well as other forms of international cooperation (Trade Finance 2019). The China Construction Bank has developed various financial products to match 
the needs of infrastructural projects at different stages of construction. Meanwhile, the Industrial and Commercial Bank of China has initiated the Belt and Road Inter-bank Regular Cooperation Mechanism that brings together 94 financial institutions from $5^{1}$ countries for co-financing and other forms of collaboration (Hu at al. 2019).

Another source of financing for BRI projects is the Silk Road Fund. This is a medium- and long-term development and investment fund, established based on the investment from a number of state agencies. The fund carries out equity and debt investment for infrastructure, resources and energy development, industrial capacity cooperation and financial cooperation under the BRI and it also invests in other funds. Meanwhile, China Investment Corporation is a sovereign wealth fund responsible for managing part of China's enormous exchange reserves. It has increased its investment in the BRI regions, especially focusing on 'new infrastructure projects' such as telecommunication and digitalization (China News 2019). A further provider of funding for BRI projects is CITIC Group, a Chinese state-owned investment company. The company was actively engaged in overseas investment before the BRI was announced and it has developed further business interests in BRI countries since 2013 .

SOEs are technically not development finance institutions, but they channel finance and operate projects in a wide range of BRI countries. They are arguably the most important participants of the BRI. So far, 81 central SOEs have carried out more than 3400 BRI projects, including more than $60 \%$ of all the infrastructure projects under the BRI. They are the main project operators and investors in large infrastructure and energy projects (China Economic Net 2016; Xu 2020). The SOEs' BRI investments are mostly funded by Chinese policy banks and state-owned commercial banks. Although private companies are increasingly encouraged to participate in BRI projects, SOEs remain the dominant players in these projects thanks to their privilege in accessing state support.

The AIIB was proposed by the Chinese government in the same year as the BRI, namely 2013. It was initially aimed at mobilizing Asian savings and foreign exchange reserves to fill the gap in Asian countries' demand for infrastructure finance (ADB \& ADBI 2009). As more non-Asian members joined the bank, it became a truly global-scale multilateral development bank (MDB) that devotes itself to long-term infrastructure development. Nevertheless, China remains the dominant shareholder in the AIIB. As a multilateral institution, the AIIB does not directly finance China's BRI projects. These projects are typically sponsored by Chinese agencies, either solely or jointly with other government or private investors, and are operated 
by Chinese companies as primary contractors. However, the projects funded by the AIIB have geographical overlaps with the BRI projects and also share the common objective of improving infrastructure foundations and cross-border connectivity. It is fair to say that the AIIB and the BRI both reflect China's ambition for overseas expansion through infrastructure financing. China's participation in the AIIB shows its demand for a larger voice in the Asian regional governance of development finance, especially in terms of allocating financial resources and setting up rules for infrastructure development. The AIIB is also expected to stimulate a vibrant market and active government administrations for development finance in Asia, which would largely benefit the BRI. Other institutions, such as the BRICS New Development Bank as well as a potential development bank and fund that may be formed under the Shanghai Cooperation Organisation, are also seen as possible supporting multilateral institutions for the BRI (Xinhua 2018; Carrai 2018).

The MCDF was announced by China's Ministry of Finance in 2017. It is intended to provide a multilateral effort to support and coordinate BRI cooperation. So far, eight MDFIs have answered the Ministry's call and signed the MoU for establishing the Cooperation Centre. These include the Asian Development Bank (ADB), the AIIB, the Corporación Andina de Fomento, the European Bank for Reconstruction and Development, the European Investment Bank, the Inter-American Development Bank, the International Fund for Agricultural Development, and the World Bank..$^{18} \mathrm{At}$ the Second Belt and Road Forum for International Cooperation, President $\mathrm{Xi}$ Jinping endorsed the MCDF as a potentially key supporting institution for the BRI (You 2019). It has been confirmed that the AIIB will be the secretariat of the MCDF. According to the MoU, the MCDF will have three main functions:

1 Information sharing: to facilitate the flow of information across the parties and other development partners in order to avoid duplication and enhance collaboration.

2 Capacity building: to enhance relevant know-how and institutional capacity of development countries and their development partners in [...] investment climate, transparent and sustainable debt management, open procurement, environmental and social frameworks, and anti-corruption.

18 Memorandum of Understanding on Collaboration on Matters to Establish the Multilateral Cooperation Center for Development Finance, https:/www.aiib.org/en/about-aiib/who-we-are/ partnership/_download/collaboration-on-matters.pdf. 
3 Project preparation: to finance upstream activities including [...] pre-feasibility and feasibility studies, and environmental and social assessment. $^{19}$

These functions reflect the Chinese government's desire for better information and knowledge about its BRI partners, higher host country institutional capacity, and multilateral assistance in project preparation. These things are currently inadequate in many of the BRI operations, something that reveals the problems and challenges that exist with the BRI's current development finance mechanisms.

\section{Challenges in Development Finance}

As the BRI has grown to become China's grand strategy for economic expansion, its projects have faced increasing challenges that erode their financial returns. Although the BRI could create significant long-term benefits for China and its partners, numerous projects are currently facing financial losses and several have been halted indefinitely (Greer 2018). ${ }^{20}$ An OECD report indicated that, between 2005 and 2018, Chinese investors were associated with US\$101.8 billion of troubled assets in BRI regions (OECD 2018b). ${ }^{21}$ Loans made to several countries could not be repaid and China was accused of aggravating these countries' debt burdens (Abi-Habib 2018; Masood 2019; Weinland 2017; Wharton Knowledge podcast 2019; Hurley et al. 2018). This has created mounting operational risks for Chinese SOEs and financial risks for the Chinese banks. ${ }^{22}$

The challenges faced by Chinese financiers are multifaceted. First, returns on investment are associated with host countries' political, economic, and security conditions. These conditions are known to be volatile in many BRI countries. The former head of Eximbank, Li Ruogu, warned that many BRI host countries were not creditworthy (Li \& Wang 2018). Chinese investors are often inadequately prepared for the complex political structures and problems of host countries. These can include such things as a central-local

19 Ibid.

20 Greer pointed out that ' $270 \mathrm{BRI}$ infrastructure projects in the region (or $32 \%$ of the total value of the whole) have been put on hold because of problems with practicality or financial viability'.

21 'Troubled' means: the collateral value of the investment is below its liabilities; loans are not performing; the deal has been cancelled for delays in reviews or political opposition, and so on. 22 CDB's non-performance loans have increased according to its 2018 annual report. (CDB 2018). 
division, fierce competition among local regions, inconsistency between different elected governments, and corruption (Arduino \& Cainey 2019). Many BRI countries also tend to have weak industrial foundations, for example, low labour productivity, energy inadequacy, and low efficiency. They also tend to have poorer investment environments when compared to developed economies, as well as large debt issues (Jamal 2017; Arduino \& Cainey 2019). In 2017, the sovereign debt of 27 of the countries participating in BRI was rated as 'junk' by the three main rating agencies - Standard and Poor's, Moody's, and Fitch Group. Another fourteen participating countries were either not rated or had withdrawn their requests for ratings (Deloitte Insights 2018). Several BRI projects have also been interrupted by security threats in the host countries. These features create extra risks. Chinese investors can rush into locking in deals, based on a benign diplomatic relationship with the host countries, without thorough due diligence or adequate pre-project viability analysis. In addition, since the Chinese investors tend to adopt a 'non-interference' approach and distance themselves from host countries' local politics, they may be less responsive to the problems that emerge during projects (Russel \& Berger 2019).

Second, some BRI projects face strong resistance from the local communities in host countries. Infrastructure projects often incur negative social and environmental impacts, especially regarding land acquisition, migrant compensation, and labour abuse (Reed \& Hille 2019). In some cases, financial compensation is inadequate for migrants, who are forced to move and lose their means of living and social facilities to infrastructure projects. In such cases, Chinese investors' capacity to carry out environmental and social management can be challenged and questioned. Some Chinese overseas infrastructure projects have been criticized for lacking environmental and social conflict research and management (Russel \& Berger 2019; Gransow \& Price 2018). They have also received criticism for dismissing communication with the media, non-governmental organizations, ethnical minorities, and the lower strata population in the host countries (Jiang 2014). A report by the environmental organization Friends of the Earth International has indicated that the 'mining, oil and gas, large-scale hydropower and large-scale agriculture sectors in which CDB invests carry tremendous environmental and social risk' (Friends of the Earth 2012). Some improvements have recently been made to how both Chinese banks and SOEs approach environmental and social management, but further measures are needed. ${ }^{23}$

23 For example, the CDB publishes its environmental policy and performance data, participates in international initiatives to improve its environmental and social performance and finances 
Third, China's ambitious BRI, as a grand strategy for the outward economic expansion, has caused anxiety in its regional competitors, such as India and Japan. India sees China's BRI projects in Pakistan, Sri Lanka, and Bangladesh as a threat to its leadership in the South Asian regional economic and security orders. It has been sceptical about the BRI from the early days and refused to sign a BRI MoU (Kamdar 2019; Economic Times 2019b). Japan was the sole Asian regional leader in development finance for a long time after the Second World War, as well as the largest regional aid provider. Unsurprisingly therefore, the possibility that China may take over regional development finance leadership through the BRI has not been well received in Japan and it has refused to join the China-led AIIB (Pesek 2019). Territorial disputes with China, such as the Diaoyu/Senkaku Islands dispute between China and Japan and the recent disputes between China and India near Tibet and on the disputed Doklam plateau, have further dissuaded both Asian powers from endorsing the BRI. The BRI has also caused uneasiness in the West (Economic Times 2019a; Balding 2018). US and European governments and companies have criticized the Chinese state's intervention in BRI projects and Chinese SOEs' dominance in these projects on the grounds that they cause unfair competition and erode the benefits of non-Chinese partners (Chance 2016). The US is wary about China's rise, especially when this rise is achieved through economic links with some of the US-dominated regions, such as the Middle East and Latin America. The US has therefore refused to hail the Chinese leadership in development finance and rejected the AIIB. As discussed above, the EU sees some potential benefits of the BRI but has been cautious about China's engagement with Central and Eastern European countries and its impact on European integration (Kynge \& Peel 2017). Overall, tensions between China and other great powers have created large obstacles for the BRI.

Last but not least, the growth of the Chinese economy has slowed since 2008. This slowdown has also been accompanied by mounting corporate and local government debts, decreasing foreign exchange reserves, and worsening financial instability (Bloomberg 2017). The Chinese government tightened controls on overseas investment in 2016 as capital flight increased and the

renewable energy projects (Friends of the Earth 2012). The Chinese State Council now holds SOE managers responsible for their bad investment decisions, and disciplinary actions could be taken against them even after they retire (Thomas \& Price 2017). In November 2017, the China Banking Regulatory Commission issued its first regulations for China's policy banks, emphasizing greater risk controls for their overseas activities (Wu \& Jia 2017). In August 2018, Beijing issued policy papers to its SOEs involved in BRI projects regarding issues such as due diligence, project feasibility and ongoing operations (Deloitte Insights 2018). 
domestic economic slowdown continued (Reuters 2017). Since most of the BRI projects are financed by Chinese capital, a further economic slowdown in China may weaken the state's capacity to support the BRI. On the other hand, this makes good investment decisions and project management urgently important for Chinese financiers and projects operators (SOEs).

\section{Driving Factors in Development Finance}

Based on the examples of the AIIB and the MCDF, China's engagement with multilateral development finance institutions to smooth BRI cooperation is motivated by both efficiency and strategic concerns.

The MCDF's institutional design and its functions reveal China's concerns with the efficiency issues of existing BRI projects. Other than the Chinese Ministry of Finance itself, all the other MCDF members are MDFIs. China has had satisfactory collaboration with all these institutions. Among others, China has significantly benefited from the financial and technical assistance of the World Bank and the Asian Development Bank in the past four decades. These multilateral institutions have rich experience and substantial institutional capacity in dealing with the issues of development projects. They hire a large number of development experts to work on project preparation and post-investment management. The staff members in these institutions move internally between different regional and thematical departments, creating a vibrant internal knowledge and expertise mobility. Most of the MDFIs also have an in-house research department that focuses on in-depth studies of a wide range of development issues and provides intellectual support for their policy decisions. Therefore, they have developed a rather comprehensive understanding of developing regions, including many BRI countries.

The MDFIs have developed advanced practices to ensure the efficiency of development projects. For example, the public procurement guidelines of the World Bank and other MDBs encourage the use of competition in the allocation of contracts through open tendering, indicate clear evaluation criteria for determining the winning bid, and prevent collusion between bidders. Compared to the MDB guidelines, China's domestic Government Procurement Law and Bidding Law tend to support the award of BRI contracts to preferred Chinese suppliers (Ghossein et al. 2018), which constrains the allocative efficiency of BRI projects in the long run. Moreover, MDFIs often play a leading role in the area of environmental and social management. For example, both the World Bank and the International Finance Corporation have developed industry-specific social and environmental 
guidelines. The Equator Principles, prominent risk management guidelines for financial institutions, were based on the International Finance Corporation's environmental and social policy frameworks. However, the Chinese policy banks lag behind their international peers: the CDB and Eximbank did not join the Equator Principles and they have not adopted widely accepted guidelines for a grievance mechanism either (Suzuki 2007; Gallagher 2016). The MDFIs also work more closely with the media and non-governmental organizations, whose voices are crucial for a successful development project. All in all, the MCDF, through information sharing, capacity building, and project preparation, is expected to bring together experienced and capable MDFIs to help China fight the challenges it faces in BRI projects so that it can avoid loss and/or maximize the return on investments. Hence, the MCDF answers to China's efficiency concerns.

In addition, by establishing and participating in multilateral institutions like the AIIB and MCDF, China can strengthen its influence in rule setting and decision making in the area of development finance in general and in BRI countries in particular. The AIIB's institutional innovations, such as the sole focus on infrastructure development, the non-resident board of directors, and the simplified project preparation procedures (compared to the World Bank), reflect China's preferred alternative approach to multilateral development finance compared to the traditionally Western-led MDBs. The MCDF's institutional set-up, where there are MDFIs instead of sovereign states as members, also allows China to avoid direct confrontations with its regional and global great-power rivals in discussion of the BRI. The US has been vigilant about the World Bank joining China's multilateral initiative for supporting the BRI, but it cannot directly intervene in the interactions between the bank and China under the MCDF set-up. Therefore, China's multilateral approach to BRI cooperation, through the AIIB and MCDF, is also driven by strategic concerns.

\section{Conclusion}

In dealing with the varied challenges of the BRI, the Chinese government lacks an integral governance framework that systemically coordinates all the relevant institutions. Instead, it has developed different institutional approaches in various issue areas. Our analysis shows that Beijing's institutional approaches in the issue areas of trade, tax, and development finance are driven by two main concerns: 1) an 'efficiency concern' to reduce transaction costs and maximize economic advantages in BRI 
Figure 3.1 Dominant drivers of China's institutional approach by issue area
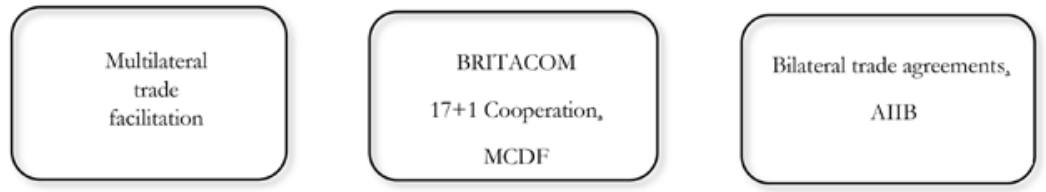

Source: Author's compilation of data from UNCTAD. ${ }^{24}$

cooperation; and 2) a 'strategic concern' to strengthen China's strategic position in the governance of BRI affairs. By taking a closer look at each issue area, we find that efficiency and strategic concerns drive Beijing to make different institutional choices even within the same issue area (see figure 3.1).

On the spectrum of factors driving China's institutional approach, we conclude that the design of its various bilateral and regional trade agreements is driven primarily by strategic considerations. We reach this conclusion for two reasons. First, the BRI itself was at least partially devised as a response to the challenge of the Trans-Pacific Partnership (TPP), which, given its exclusion of China, Beijing perceived as a threat to its regional influence. Second, China's approach to trade deals with BRI partner countries, beginning with shallow and limited agreements that are subsequently expanded in numerous rounds of negotiations over many years, has a number of consequences. It maximizes the opportunity costs resulting from the lack of an initially comprehensive deal, it increases uncertainty, and it raises negotiation costs. At the same time this approach maximizes China's bargaining power as the dependence of its trade partners grows. In contrast, the multilateral cooperation around trade facilitation seems to be driven primarily by efficiency concerns, namely a concern to minimize the costs of cross-border trade with BRI partners. The efforts on this front, however, are piecemeal and slow, with limited results, largely due to capacity constraints in partner countries.

The tax institutions of the BRI meanwhile are driven by the need for reduction of transaction costs accompanied by a desire to create a competing 
regulatory model that can challenge dominant Western approaches. The use of MoUs and cooperation mechanisms (the BRITACOM, and the $17^{+1}$ cooperation in the EU) has shown China's interest in dealing with the BRI in accordance with the needs of China's businesses. This is mainly due to efficiency concerns. However, there are also some strategic reasons behind these choices, since China has chosen to deal directly with EU countries rather than with the EU as a whole. This has created uncertainty in the EU and among EU businesses about whether the benefits of the BRI are only for Chinese investors or also for EU investors. China will need to address these concerns and ensure that the BRI provides clear benefits for all countries involved.

In the governance of development finance, China's engagement with the MCDF and the AIIB is motivated by both efficiency and strategic concerns. By establishing the MCDF, Beijing hopes to bring together experienced and capable MDFIs. These can help China fight the challenges it faces in BRI projects so that it can avoid financial loss and/or maximize return on investments. Hence, the MCDF answers to China's efficiency concerns. Meanwhile, through participating in China-dominated multilateral institutions like the AIIB and MCDF, Beijing aims to strengthen its influence in rule setting and decision making in the area of development finance. This reflects China's strategic concerns in BRI cooperation. That being said, since the AIIB has only been operational since 2016, and the MCDF has not yet started operating, their long-term impacts on BRI remain to be seen.

Attempts to answer questions about what factors drive China's approach to the BRI have often been too imprecise to be useful. By focusing on specific sub-areas within the broader BRI project in this chapter, it is clear that the factors driving China's policy differ in important ways across issue areas. We conclude that analyses that fail to recognize this complex reality are likely to draw flawed inferences regarding the complex motivations driving China's behaviour when it comes to the BRI.

\section{Acknowledgements}

The writing and research carried out for this chapter are the result of research in the framework of the GLOBTAXGOV Project. This project has received funding from the European Research Council (ERC) under the European Union's Seventh Framework Programme (FP/2007-2013) (ERC Grant agreement no. 758671). 


\section{References}

Abi-Habib, Maria (2018, June 25). 'How China Got Sri Lanka to Cough up a Port'. New York Times. Retrieved 4 August 2020 from https://www.nytimes.com/2018/06/25/ world/asia/china-sri-lanka-port.html.

ADB \& ADBI (2009). Infrastructure for a Seamless Asia. Manila: Asian Development Bank and Asian Development Bank Institute.

Arduino, Alessandro \& Cainey, Andrew (2019). 'Risk Assessment and Mitigation in Central Asia: Implications for Foreign Direct Investment and the Belt and Road Initiative'. European Bank for Reconstruction and Development (EBRD). Avi-Yonah, Reuven \& Xu, Haiyan (2017). 'China and the Future of the International Tax Regime'. Law \& Economics Working Paper. Retrieved 3 August 2020 from https://repository.law.umich.edu/cgi/viewcontent.cgi?article $=1249 \&$ context=law_ econ_current.

Balding, Christopher (2018). 'Why Democracies Are Turning against Belt and Road: Corruption, Debt and Backlash'. Foreign Affairs. Retrieved 4 August 2020 from https://www.foreignaffairs.com/articles/china/2018-10-24/why-democraciesare-turning-against-belt-and-road.

Baltensperger, M. \& Dadush, U. (2019). 'The Belt and Road Turns Five'. Russian Journal of Economics, 5(2), 136-153.

Beng Teoh, Choon \& Wang, Xiaoyue (2019, December 3). 'China Transfer Pricing Enforcement: Modernised Approach Matures'. International Tax Review. Retrieved 3 August 2020 from https://www.internationaltaxreview.com/article/bij8xvh3y7f3pb/ china-transfer-pricing-enforcement-modernised-approach-matures.

Boffa, Mauro (2018, May). 'Trade Linkages between the Belt and Road Economies'. World Bank Policy Research Working Paper.

Blockmans, Steven \& Hu, Weinian (2019). 'Systemic Rivalry and Balancing Interests: Chinese Investment Meets EU Law on the Belt and Road'. CEPS Policy Insights no. 4. Retrieved 3 August 2020 from https://www.ceps.eu/wp-content/ uploads/2019/03/PI_2019_04_SB-WH_EU-China_o.pdf.

Bloomberg (2017, November 4). 'China's Central Bank Chief Warns of "Sudden, Contagious and Hazardous" Financial Risks'. Bloomberg. Retrieved 4 August 2020 from https://www.bloomberg.com/news/articles/2017-11-04/ china-s-zhou-warns-on-mounting-financial-risk-in-rare-commentary.

BRITACOM (n.d.). 'The Belt and Road Initiative Tax Administration Cooperation Mechanism'. Retrieved 3 August 2020 from http://www.chinatax.gov.cn/eng/ n4260869/c5112279/content.html.

Brookings (2019). 'Winners and Losers along China's Belt and Road'. Retrieved 6 March 2020 from https://www.brookings.edu/blog/future-development/ 2019/o6/21/winners-and-losers-along-chinas-belt-and-road/. 
BusinessEurope (2020, January). The EU and China:Addressing the Systemic Challenge. Brussels: BusinessEurope. Retrieved 25 June 2020 from https://www. businesseurope.eu/publications/eu-and-china-addressing-systemic-challenge. Carrai, Maria Adele (2018). 'It Is Not the End of History: The Financing Institutions of the Belt and Road Initiative and the Bretton Woods System'. In Julien Chaisse \& Jędrzej Górski (eds.), The Belt and Road Initiative: Law Economics and Politics (pp. 107-145). Leiden: Brill.

CDB (2018). Annual Report. China Development Bank. Retrieved 4 August 2020 from http://www.cdb.com.cn/English/bgxz/ndbg/ndbg2018/.

Chance, Alek (2016). 'American Perspectives on the Belt and Road Initiative: Sources of Concern and Possibilities for Cooperation'. Washington, DC: Institute for ChinaAmerica Studies. Retrieved 4 August 2020 from https://chinaus-icas.org/wp-content/ uploads/2017/02/American-Perspectives-on-the-Belt-and-Road-Initiative.pdf.

Cheng, Chi, et al. (2019, January 29). 'Now That China Has Data, What Is It Going to Do with It?' International Tax Review. Retrieved 3 August 2020 from https://www.internationaltaxreview.com/article/b1fydc6pd5rw7c/ now-that-china-has-data-what-is-it-going-do-with-it.

China Economic Net [中国经济网] (2016, December 6). “首届“一带一路”企业贡献 排行榜评选公示' [Announcement of the first 'Belt and Road Initiative' ranking of corporation contributions]. Retrieved 4 August 2020 from http://intl.ce.cn/ specials/zxgjzh/201612/o6/t20161206_18418097.shtml.

China News (2019, March 29). “屠光绍: 中投在“一带一路”眼线国家已投资241亿美 元' [Tu Guangshao: China Investment Corporation has invested US\$24.1 billion in 'Belt and Road Initiative' countries]. China News. Retrieved 4 August 2020 from https://www.chinanews.com/cj/2019/03-29/8794847.shtml.

Cui, Lianbiao \& Song, Malin (2019). 'Economic Evaluation of the Belt and Road Initiative from an Unimpeded Trade Perspective'. International Journal of Logistics Research and Applications, 22(1), 25-46.

Deloitte Insights (2018). Embracing the BRI Ecosystem in 2018: Navigating Pitfalls and Seizing Opportunities. Deloitte China. Retrieved 26 October 2020 from https://www2.deloitte.com/content/dam/insights/us/articles/4406_Belt-androad-initiative/4406_Embracing-the-BRI-ecosystem.pdf.

De Soyres, François, Mulabdic, Alen, Murray, Siobhan, Rocha, Nadia \& Ruta, Michele (2019). 'How Much Will the Belt and Road Initiative Reduce Trade Costs?' International Economics, 159(July), 151-164.

Economic Times (2018). 'Pakistan Government Plans to Renegotiate Agreements Reached under China's BRI: Report'. Economic Times. Retrieved 6 March 2020 from https://economictimes.indiatimes.com/news/international/world-news/ pakistan-government-plans-to-renegotiate-agreements-reached-under-chinasbri-report/articleshow/65755576.cms?from=mdr. 
Economic Times (2019a, May 9). “Fed Up” of US Criticism of BRI, Says China'. Economic Times. Retrieved 4 August 2020 from https://economictimes.indiatimes. com/news/international/business/fed-up-of-us-criticism-of-bri-says-china/ articleshow/69253669.cms.

Economic Times (2019b, October 4). 'India Won't Join BRI, Its Concept Won't Apply to Us: Jaishankar'. Economic Times. Retrieved 4 August 2020 from https://economictimes.indiatimes.com/news/politics-and-nation/indiawont-join-bri-its-concept-wont-apply-to-us-jaishankar/articleshow/71441347. $\mathrm{cms}$ ?from $=\mathrm{mdr}$.

EU Commission (2018, September 28). ‘Commission Approves Hungary’s €45 Million Investment Aid to BorsodChem'. Press release. Retrieved 3 August 2020 from https://ec.europa.eu/commission/presscorner/detail/en/IP_18_5941.

EU Commission (2019, March 12). 'Joint Communication to the European Parliament, the European Council and the Council: EU-China - A Strategic Outlook'. JOIN(2019) 5 final. Retrieved 3 August 2020 from https://ec.europa.eu/commission/sites/beta-political/files/communication-eu-china-a-strategic-outlook.pdf.

Friedman, Milton (1953). 'Essays in Positive Economics Part I - The Methodology of Positive Economics'. Press II, 3-43.

Friends of the Earth (2012). China Development Bank's Overseas Investments: An Assessment of Environmental and Social Policies and Practices. Berkeley, CA: Friends of the Earth.

Gallagher, Kevin (2016). The China Triangle: Latin America's China Boom and the Fate of the Washington Consensus. Oxford: Oxford University Press.

Ghossein, Tania, Hoekman, Bernard M. \& Shinhal, Anirudh (2018). 'Public Procurement in the Belt and Road Initiative'. MTI Discussion Paper no. 10. Washington, DC: World Bank.

Gransow, Bettina \& Price, Susanna (2018). 'Social Risk Management at AIIB Chinese or International Characteristics?' Journal of Chinese Political Science, 24, 289-311.

Greer, Tanner (2018, December 6). 'One Belt, One Road, One Big Mistake: China's Signature Foreign-Policy Project Is a Failure That the US Should Copy'. Foreign Policy. Retrieved 4 August 2020 from https://foreignpolicy.com/2018/12/o6/ bri-china-belt-road-initiative-blunder/.

Haider, Irfan (2015, April 20). 'Details of Agreements Signed during Xi's Visit to Pakistan'. Dawn. Retrieved 1 September 2020 from https://www.dawn.com/ news/1177129.

Hanemann, Thilo, Huotari, Mikko \& Kratz, Agatha (2019). 'Chinese FDI in Europe: 2018 Trends and Impact of New Screening Policies'. Meric Papers on China. Retrieved 3 August 2020 from https://rhg.com/wp-content/uploads/2019/03/ RHG-MERICS-COFDI-Update-2019.pdf. 
Hogan, Phil (2020, January 20). 'Speech by Commissioner Phil Hogan at the Publication of BusinessEurope's Strategy Paper on the EU-China Economic Relations'. European Commission. Retrieved 3 August 2020 from https://ec.europa.eu/commission/commissioners/2019-2024/hogan/announcements/speech-commissionerphil-hogan-publication-business-europes-strategy-paper-eu-china-economic_en. Hu, Pingchao, Yu, Rui \& Zhang, Aifang (2019, April 24). 'Belt and Road Inter-bank Regular Co-op Promotes Financial Integration'. Xinhua Silk Road Information Service.

Hurley, John, Morris, Scott \& Portelance, Gailyn (2018, March). 'Examining the Debt Implications of the Belt and Road Initiative from a Policy Perspective'. CGD Policy Paper 121. Washington, DC: Center for Global Development.

Jamal, Nasir (2017, March 12). 'The Cost of CPEC'. Dawn. Retrieved 4 August 2020 from https://www.dawn.com/news/1320028.

Jiang, Heng (2014). 'Blind Spots and Erroneous Understanding of Environmental and Social Risks Overseas'. In Daojiong Zha, Fusheng Li \& Heng Jiang (eds.), Chinese Overseas Investment: Case Studies on Environmental and Social Risk (pp. 35-56). Beijing: Peking University Press.

Jiang, Xueqing (2019, April 12). 'Bank of China Issues BRI-Related Bonds'. China Daily. Retrieved 4 August 2020 from https://www.chinadaily.com.cn/a/201904/12/ WS5cafdo67a310484226ob5bfa.html.

Johns, Marcus Bartley, Clarke, Julian Latimer, Kerswell, Clay \& McLinden, Gerard (2018). 'Trade Facilitation Challenges and Reform Priorities for Maximizing the Impact of the Belt and Road Initiative'. Discussion Paper, MTI Global Practice no. 4. World Bank, September. Retrieved 1 September 2020 from http://documents1.worldbank.org/curated/pt/219761536948259167/pdf/Trade-Facilitation-Challenges-andReform-Priorities-for-Maximizing-the-Impact-of-the-Belt-and-Road-Initiative.pdf. Johnston, Lauren A. (2019). 'The Belt and Road Initiative: What Is in It for China?' Asia and the Pacific Policy Studies, 6(1), 40-58. Retrieved 1 September 2020 from https://doi.org/10.1002/app5.265.

Kamdar, Bandari. (2019, May 9). 'What to Make of India's Absence from the Second Belt and Road Forum?' The Diplomat. Retrieved 4 August 2020 from https://thediplomat.com/2019/05/what-to-make-of-indias-absencefrom-the-second-belt-and-road-forum/.

Kynge, James \& Peel, Michael (2017, November 27). 'Brussels Rattled as China Reaches out to Eastern Europe'. Financial Times. Retrieved 4 August 2020 from https://carnegieendowment.org/2018/10/19/europe-s-emerging-approachto-china-s-belt-and-road-initiative-pub-77536.

Li, Jinyan (2012). 'The Great Fiscal Wall of China: Tax Treaties and Their Role in Defining and Defending China's Tax Base'. Bulletin International Taxation, 66(9), 452-479. 
Li, Liuxi \& Wang, Fran (2018, April 18). 'Ex-China EximBank Chief Warns that Many BRI Host Countries Are Not Credit Worthy'. NewsIn Asia. Retrieved 4 August 2020 from https://newsin.asia/ex-china-eximbank-chief-warns-that-many-bri-hostcountries-are-not-credit-worthy/.

Masood, Salman (2019, May 12). 'Pakistan to Accept \$6 Billion Bailout from IMF'. New York Times. Retrieved 4 August 2020 from https://www.nytimes.com/2019/05/12/ world/asia/pakistan-imf-bailout.html.

Masseglia Miszczyszyn, Elena, Lamensch, Marie, Traversa, Edoardo \& Villar Ezcurra, Marta (2020). 'The EU-China Trade Partnership from a European Tax Perspective'. CEU Working Paper no. 6o. Retrieved 3 August 2020 from https:// www.ceuediciones.es/catalogo/libros/economia/the-eu-china-trade-partnershipfrom-a-european-tax-perspective/.

Memorandum of Cooperation (2017, July). 'Between China, Brazil, Russia, India and South Africa'. Retrieved 3 August 2020 from http://receita.economia.gov.br/ noticias/ascom/2017/julho/receita-federal-participa-de-reuniao-dos-paises-brics/ moc-signing-version.pdf.

Memorandum of Understanding (2019a, April). 'On a Dialogue in the Area of the State Aid Control Regime and the Fair Competition Review System between the State Administration for Market Regulation of the People's Republic of China and the Directorate-General for Competition of the European Commission'. Retrieved 3 August 2020 from https://ec.europa.eu/competition/international/ bilateral/mou_china_2019.pdf.

Memorandum of Understanding (2019b, March). 'Between the Government of the Italian Republic and the Government of the People's Republic of China on Cooperation within the Framework of the Silk Road Economic Belt and the 21st Century Maritime Silk Road Initiative'. Retrieved 1 September 2020 from http://www.governo.it/sites/governo.it/files/Memorandum_Italia-Cina_EN.pdf.

Meyer-Nandi, Sathi, et al. (2018). 'Tax Treaties Between Belt and Road Countries'. In Michael Lang \& Joeffrey Owens (eds.), Removing Tax Barriers to China's Belt and Road Initiative (pp. 197-258). Amsterdam: Wolters Kluwer.

NDRC (2015, March). 'Vision and Actions on Jointly Building Silk Road Economic Belt and 21st-Century Maritime Silk Road'. National Development and Reform Commission, Ministry of Foreign Affairs and Ministry of Commerce, People's Republic of China. Retrieved 25 October 2020 from https://web.archive.org/web/20181127225143/ http://en.ndrc.gov.cn/newsrelease/201503/t20150330_669367.html.

$\operatorname{OECD}(2017)$. 'Transfer Pricing Guidelines for Multinational Enterprises and Tax Administrations'. Organisation for Economic Co-operation and Development. Retrieved 1 September 2020 from https://www.oecd-ilibrary.org/taxation/oecd-transferpricing-guidelines-for-multinational-enterprises-and-tax-administrations-2017/ glossary_tpg-2017-4-en. 
OECD (2018a). 'BEPS MLI Position China'. Organisation for Economic Co-operation and Development. Retrieved 3 August 2020 from http://www.oecd.org/tax/ treaties/beps-mli-position-china.pdf.

OECD (2018b). 'China's Belt and Road Initiative in the Global Trade, Investment and Finance Landscape'. OECD Business and Finance Outlook 2018. Paris: Organisation for Economic Co-operation and Development.

Okano-Heijmans, Maaike \& Kamo, Tomoki (2019, May). 'Engaging but Not Endorsing China's Belt and Road Initiative'. Policy Brief. Clingendael Netherlands Institute of International Relations. Retrieved 3 August 2020 from https://www.clingendael. org/sites/default/files/2019-05/PB_China_Belt_and_Road_Initiative_May_2019.pdf.

Pesek, William (2019, October 9). 'EU-Japan Axis Emerges to Counter China's BRI'. Asia Times. Retrieved 4 August 2020 from https://asiatimes.com/2019/10/ eu-japan-axis-emerges-to-counter-chinas-bri/.

Powell, R. (1991). 'Absolute and Relative Gains in International Relations Theory'. American Political Science Review, 85(4), 1303-1320.

Rachman, Gideon (2019, March 11). 'The US, China and the Return of a Two-Bloc World'. Financial Times.

Rahman, S.U. \& Shurong, Z. (2017). 'Analysis of Chinese Economic and National Security Interests in China-Pakistan Economic Corridor (CPEC) under the Framework of One Belt One Road (OBOR) Initiative'. Arts and Social Sciences Journal, 8(4). Retrieved 1 September 2020 from https://doi.org/10.4172/2151-6200.1000284.

Ramasamy, Bala, Yeung, Matthew, Utoktham, Chorthip \& Duval, Y. (2017). 'Trade and Trade Facilitation along the Belt and Road Initiative Corridors'. ARTNeT Working Paper Series 172. Retrieved 1 September 2020 from http://artnet.unescap.org.

Reed, John \& Hille, Kathrin (2019, October 30). 'Laos's Belt and Road Project Sparks Questions over China Ambitions'. Financial Times. Retrieved 4 August 2020 from https://www.ft.com/content/a8dobdae-e5bc-11e9-9743-db5a370481bc.

Reuters (2017, January 18). 'China Steps up Capital Controls, Tightens Investment Rules for State Firms'. Reuters. Retrieved 4 August 2020 from https://www. reuters.com/article/us-china-economy-foreigninvestment-state/china-stepsup-capital-controls-tightens-investment-rules-for-state-firms-idUSKBN152oU1.

Reuters (2019, March 27). 'China Development Provides over \$19o Billion for Belt and Road Projects'. Reuters. Retrieved 4 August 2020 from https://www.reuters. com/article/us-china-finance-cdb-bri/china-development-bank-provides-over190-billion-for-belt-and-road-projects-idUSKCN1R8o95.

Russel, Daniel R. \& Berger, Blake (2019). 'Navigating the Belt and Road Initiative'. Report. Asia Society Policy Institute.

Sampson, Michael (2019). 'The Evolution of China's Regional Trade Agreements: Power Dynamics and the Future of the Asia-Pacific'. Pacific Review. Retrieved 1 September 2020 from https://doi.org/10.1080/09512748.2019.1660397. 
Sampson, Michael (2020, February 5). 'Expanding Influence: China's Evolving Trade Agreements in the Asia-Pacific'. The Diplomat. Retrieved $3 \mathrm{Au}-$ gust 2020 from https://thediplomat.com/2020/02/expanding-influencechinas-evolving-trade-agreements-in-the-asia-pacific/.

Sanderson, Henry \& Forsythe, Michael (2013). China's Superbank:Debt, Oil and Influence - How China Development Bank Is Rewriting the Rules of Finance. Singapore: Wiley. Suzuki, Eisuke (2007). 'Bilateral Policy Orientation in the Multilateral Development Policy: A Challenge for the China Exim Bank and Its Accountability'. Chinese Journal of International Law, 6(1), 127-133.

Thomas, Denny \& Price, Michelle (2017, September 27). 'When Deals Go Bad: China State Firm Managers Spooked by New Liability Rules'. Reuters. Retrieved $4 \mathrm{Au}-$ gust 2020 from https://www.reuters.com/article/us-china-soe-m-a/when-deals-gobad-china-state-firm-managers-spooked-by-new-liability-rules-idUSKCNıW2LW. Trade Finance [贸易金融] (2019, May 9). “农业银行: 推进“一带一路”及国际金 融服务体系建设' [Agricultural Bank of China: Pushing forward the 'Belt and Road Initiative' and the construction of the international financial service system]. Trade Finance. Retrieved 4 August 2020 from http://www.sinotf.com/ GB/yuanchuang/1110/2019-05-09/4OMDAwMDMzMzM4OQ.html.

United Nations (2014). 'China's Response' [The United Nations questionnaire on BEPS]. Retrieved 3 August 2020 from https://www.un.org/esa/ffd/wp-content/ uploads/2014/10/ta-BEPS-CommentsChina.pdf.

Van der Eijk, Femke \& Pandita Gunavardana, Angela (2019). 'The Road That Divided the EU: Italy Joins China's Belt and Road Initiative'. European Law Blog. Retrieved 3 August 2020 from https://europeanlawblog.eu/2019/06/25/ the-road-that-divided-the-eu-italy-joins-chinas-belt-and-road-initiative/.

Vines, D. (2018). The BRI and RCEP: ensuring cooperation in the liberalisation of trade in Asia. Economic and Political Studies, 6(3), 338-348. https://doi.org/10.1 o8o/20954816.2018.1498992

Wang, Y. (2016). Offensive for defensive: the belt and road initiative and China's new grand strategy. Pacific Review, 29(3), 455-463. https://doi.org/10.1080/0951 2748.2016.115469o

Wei, C., Zhigao, L., Tao, W., \& Won SONN, J. (2018). The structure and evolution of trade relations between countries along the Belt and Road. 28(9), 1233-1248. https://doi.org/10.1007/s11442-018-1522-9

Weinland, Don (2017, January 25). 'China Warned of Risk to Banks from One Belt, One Road Initiative'. Financial Times. Online: https://www.ft.com/ content/6o76cf9a-e38e-11e6-8405-9e558od6e 5fb

Wharton Knowledge podcase (2019, April 30) ‘China's Belt and Road Initiative: Why the Prices is Too High'. https://knowledge.wharton.upenn.edu/article/ chinas-belt-and-road-initiative-why-the-price-is-too-high/ 
Williamson, O. E. (1985). The economic institutions of capitalism. New York: Free Press.

Wu, Xiaomeng \& Jia, Denise (2017, November 15). 'New Rules Released on Policy Banks to Enhance Risk Control'. Caixin. Retrieved 4 August 2020 from https:/ www.caixinglobal.com/2017-11-16/new-rules-released-on-policy-banks-toenhance-risk-control-10117139o.html.

Xinhua (2018, June 10). 'China to Set up 20-bln-yuan Lending Facility Under SCO Framework:Xi'. Xinhua. Retrieved 4 August 2020 from http://www.xinhuanet. com/english/2018-06/10/c_137243965.htm.

Xinhua (2019a, April 22). 'China Exim Bank’s B\&R Loans Surpasses it Yuan'. Xinhua. Retrieved 4 August 2020 from http://www.chinadaily.com.cn/a/201904/22/ $\mathrm{WS}_{5}$ cbd71eoa310484226ob7919.html.

Xinhua (2019b, April 24)، ‘四大行各展身手, 多元化服务一带一路'建设” [The Big Four show their expertise, multiple services for the 'Belt and Road Initiative' construction]. Xinhua. Retrieved 4 August 2020 from http://www.xinhuanet. com/money/2019-04/24/c_1124409185.htm.

Xu, Beibei (2020, January 15). '81家央企在”一带一路”沿线承担超3400 个项目' [Eighty-one central state-owned enterprises operate more than 3400 projects along the Belt and Road]. Financial News. Retrieved 4 August 2020 from http:// www.financialnews.com.cn/cj/hyfx/202001/t20200115_175279.html.

$\mathrm{Xu}$, Diheng (2018a). 'China versus the BEPS Project'. Retrieved 3 August 2020 from https:/globtaxgov.weblog.leidenuniv.nl/2018/og/o3/ china-versus-the-beps-project/.

$\mathrm{Xu}$, Diheng (2018b). 'The Convergence and Divergence between China's Implementation and OECD/G2o BEPS Minimum Standards'. World Tax Journal, 10(3). IBFD Publications. 471-496.

You, Runtian (2019, April 26). ‘习近平: ‘一带一路’一切合作将在阳光下运作, 以 零容忍态度打击腐败’ [Xi Jinping: All ‘Belt and Road Initiative’ cooperation will operate under the sunshine, striking on corruption with zero tolerance]. Belt and Road. Retrieved 4 August 2020 from https://beltandroad.zaobao.com/ beltandroad/news/story20190426-951782.

Zhang, Kangle (2018). 'A Tale of Ending Poverty: The New Financial Institutions and China's Global Strategy'. In Wenhua Shan, Kimmo Nuotio \& Kangle Zhang (eds.), Normative Readings of the Belt and Road Initiative (pp. 105-127). Cham: Springer International Publishing.

Zhang, Mo (2019, April 16). ‘中行”一带一路’主题债券规模近 150 亿美元”. 经济参 考报' ['Belt and Road Initiative'-themed bonds issued by Bank of China have reached US $\$ 15$ billion]. Chinabond.com. Retrieved 4 August 2020 from https:// www.chinabond.com.cn/cb/cn/xwgg/zsxw/zqsc/jrz/20190416/151335892. shtml. 


\section{About the Authors}

Michael SAmpson is Assistant Professor of International Relations at Leiden University's Institute of Political Science. His research focuses on international political economy and the strategic and distributional consequences of trade institutions.

JUE WANG is a Lecturer at the Leiden University Institute for Area Studies. She is a scholar of international political economy, with a focus on China, its external economic relationships, and its role in regional and global economic governance. She also has a wide range of research interests in international economic organizations, international cooperation, and the development of emerging economies. Her academic work has been published in, amongst others, International Affairs and the Chinese Political Science Review. She is also an Associate Fellow in the Asia-Pacific Programme at Chatham House. She regularly comments on Chinese and international affairs for media outlets, including the BBC, CGTN, Al Jazeera, the New York Times, and The Times.

Irma Mosquera VAlderrama is Associate Professor of Tax Law at Leiden University, the Netherlands. She obtained her PhD (cum laude) in 2007 at the University of Groningen, the Netherlands. Her areas of expertise are international tax law and comparative tax law in developed and developing countries and, more recently, exchange of information, including taxpayers' rights and safeguards in exchange of information and BEPS-related issues in developing countries. She has published several articles in peer-reviewed journals and non-peer-reviewed journals. She has been awarded an ERC Starting Grant by the European Research Council to carry out research from 2018 to 2022 on a New Model of Global Governance in International Tax Law Making (GLOBTAXGOV). 
